\title{
Talent retention strategies: An exploratory study within the consulting industry in Gauteng province, South Africa
}

\begin{tabular}{|c|c|}
\hline \multicolumn{2}{|c|}{$\begin{array}{l}\text { Authors: } \\
\text { Calvin M. Mabaso } \\
\text { Malose T. Maja }^{1} \text { (D) } \\
\text { Makan Kavir }^{1} \text { (D) } \\
\text { Lesego Lekwape }^{1} \text { (D) } \\
\text { Shereen S. Makhasane }^{1} \text { (D) } \\
\text { Mbali T. Khumalo }^{1} \text { (D) }\end{array}$} \\
\hline \multicolumn{2}{|c|}{$\begin{array}{l}\text { Affiliations: } \\
\text { }{ }^{1} \text { Department of Industrial } \\
\text { Psychology and People } \\
\text { Management, College of } \\
\text { Business Economics, } \\
\text { University of Johannesburg, } \\
\text { Johannesburg, South Africa }\end{array}$} \\
\hline \multicolumn{2}{|c|}{$\begin{array}{l}\text { Corresponding author: } \\
\text { Calvin Mabaso, } \\
\text { calvinm@uj.ac.za }\end{array}$} \\
\hline \multicolumn{2}{|c|}{$\begin{array}{l}\text { Dates: } \\
\text { Received: } 17 \text { June } 2020 \\
\text { Accepted: } 01 \text { Mar. } 2021 \\
\text { Published: } 09 \text { June } 2021\end{array}$} \\
\hline \multicolumn{2}{|c|}{$\begin{array}{l}\text { How to cite this article: } \\
\text { Mabaso, C.M., Maja, M.T., } \\
\text { Kavir, M., Lekwape, L., } \\
\text { Makhasane, S.S. \& Khumalo, } \\
\text { M.T., 2021, 'Talent retention } \\
\text { strategies: An exploratory } \\
\text { study within the consulting } \\
\text { industry in Gauteng province, } \\
\text { South Africa', Acta Commercii } \\
\text { 21(1), a885. https://doi. } \\
\text { org/10.4102/ac.v21i1.885 }\end{array}$} \\
\hline \multicolumn{2}{|c|}{$\begin{array}{l}\text { Copyright: } \\
\text { (C) 2021. The Authors. } \\
\text { Licensee: AOSIS. This worl } \\
\text { is licensed under the } \\
\text { Creative Commons } \\
\text { Attribution License. }\end{array}$} \\
\hline \multicolumn{2}{|l|}{ Read online: } \\
\hline 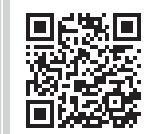 & $\begin{array}{l}\text { Scan this QR } \\
\text { code with your } \\
\text { smart phone or } \\
\text { mobile device } \\
\text { to read online. }\end{array}$ \\
\hline
\end{tabular}

Orientation: The consultancy industry globally has witnessed a paradigm shift over the past few years in terms of its nature, employee turnover and attraction and retention of talent. These changes have posed a challenge because the industry struggles to attain commitment from their employees.

Research purpose: To explore strategies to retain talent whilst ensuring performance in a consulting firm based in the south of Johannesburg, Gauteng province, South Africa.

Motivation for the study: Currently there is limited research on strategies to retain talent and enhance employee performance within the consultancy industry in South Africa. Exploring the experiences and views of consultants can assist consulting firms to develop effective retention strategies to retain talent whilst enhancing employee performance.

Research design, approach and method: A qualitative research method was adopted in this study. Semi-structured interviews were used to gather data. Thematic analysis was employed to identify patterns of meaning across the data set. Data coding was conducted on the themes that were identified. Different categories and subcategories were identified and analysed to determine themes and findings. Data collected were analysed and interpreted for meaningful conclusions. A non-probability sampling procedure was employed using purposive sampling. The sample included men and women, between 25 and 60 years of age, with a minimum of 5 years' experience as consultants in the consultancy industry in Gauteng.

Main findings: The findings show the following strategies to retain consultants in the consulting industry: (1) rewards, (2) work-life balance, (3) performance management system, (4) improved training and development, (5) employee recognition and (6) career progression opportunities.

Practical/managerial implications: The findings of this study can be used by human capital managers to develop reward systems that will enhance employee performance and retain consultants.

Contribution/value-add: This study provided important practical guidelines that could be used by consulting firms to develop and implement retention strategy valued by consultants.

Keywords: rewards; training and development; career progression; consultants; employee performance; talent retention.

\section{Introduction}

According to Consultancy (2018), the consulting industry is worth approximately R125 billion with 60000 professionals. The consulting industry accounts for over half of the African continent's overall industry and it has grown in recent years. The consultancy industry globally has however witnessed a paradigm shift over the past few years in terms of its nature, level of technology and overall scope of work (Srinivasan 2014). Over the last few decades, business consulting has recorded continuous and significant dynamic growth. The great economic relevance of the consulting industry has attracted many young professionals (Nissen 2019). However, the industry has also experienced some major changes over the past few years. These changes inform the introduction of new business processes and the approaches in designing their compensation system to retain talent. The objective of many organisations is to remain in, or gain, a competitive advantage within the market and to deliver more value to their stakeholders (Liberty 2017). This is often a challenge in the consulting industry as organisations struggle to attain commitment from their employees. The current study aims to bridge the gap by suggesting initiatives for retaining talent. In the consulting industry, which is a knowledge-intensive industry, human resources (HR) are considered to be the most important asset (Badiyala 2015), and maintaining their performance and retaining them is of particular importance. 
For service-oriented professions, such as management consulting or account management, high employee turnover leads to customer dissatisfaction and turnover, as clients feel little attachment to a revolving contact (Brian 2009). However, the industry relies on human capital in order to strive in a turbulent business environment. Therefore, performance of employees and retaining talent in the consulting industry is a major concern for managers as the industry has a high intra-industry mobility of talent (Badiyala 2015). Staff turnover in the consulting industry ranges from $15 \%$ to $20 \%$ a year and employees typically remain with their organisations for an average of 5-6 years (Work Institute 2019). It is vital for every organisation operating in a competitive environment to craft strategies to retain talent for survival. Rewards are vital to the employment relationship and play a critical role in maintaining high levels of employee performance (Misra, Rana \& Dixit 2012). To attract and retain skilled employees, organisations reward employees through monetary and non-monetary rewards systems to indicate their appreciation towards their employees (Hall-Ellis 2014). Rewards are often measured in terms of their return and monetary rewards have always been important in managing employees' performance (Callakoppen 2016). Rewards influence the performance of employees by recognising and rewarding good performance (Nwokocha \& Iheriohanma 2013). High-performing employees are seen as talented and vital to an organisation.

Attracting and retaining talented employees is a priority for many organisations (Kwenin, Muathe \& Nzulwa 2013). Letchmiah and Thomas (2017) found that employees have perceptions that organisations overlook them as assets, thus increasing staff turnover. Talented employees play a significant role in the success of an organisation. Evidence suggests that employees that have high levels of motivation and commitment are likely to remain with the organisation for a longer period of time. There are more competitors entering the market and consuming an already limited talent pool. Organisations enormously invest in recruiting and selecting employees, and then invest even more in training and developing them over time. In order to get a return on such investment, organisations need to retain well-trained employees so that they remain with the workplace for the maximum time and contribute effectively to the organisation's success. Losing good employees leads to reduction in productivity and work quality, and also represents economic costs in terms of direct costs (i.e. replacement, training and management time), and perhaps more considerably, in terms of indirect costs (i.e. morale, collaboration and pressure on remaining staff) (Al Mamun \& Hasan 2017). Limited opportunities for promotion increase performance, which leads to an increase in competition amongst employees (Larkin \& Pierce 2015). Highly talented employees usually have a greater variety of opportunities available to them. Thus, organisations need to do everything they can in order to retain the talent in their organisations.

\section{Motivation and aim of the study}

Besides the contribution to the overall economy of the country, the consulting industry has received little academic attention. Over the last few decades, business consulting has recorded continuous and significant dynamic growth. The great economic relevance of the consulting industry has attracted many young professionals (Nissen 2019). Moreover, there are only few dedicated outlets to publish research on consulting. However, even though the use of consultants and consulting firms has been prevalent for a long period, there has not been much research conducted on the same. According to Srinivasan (2014), consulting industry has received little academic attention in terms of research. This is because of various reasons, which range from lack of regulation to size and scale of the sector. The industry also faces challenges that cannot be ignored, which relate to talent retention and employee performance (Badiyala 2015). If these challenges are overlooked, it may affect the consultancy industry negatively. The industry has failed to provide a set of rewards which can successfully be used in fostering employees' performance and retention. It is projected that negative behaviour such as reduced workplace trust is a result of perceived negative incentives, for example, allowances provided are seen as not being adequate (Victor \& Hoole 2017).

Pregnolato, Bussin and Schlechter (2017) believe that groups of employees from different demographics and backgrounds value different kinds of rewards. It is essential for organisations to provide appealing rewards in order to ensure employee retention in the organisation. The insights gained from the present study aim to contribute to the implementation of effective retention strategies using rewards to improve performance and retention amongst consultants. Employee rewards have a positive impact on fostering performance amongst employees in the workplace. It is assumed that employee rewards have an impact on performance whilst ensuring talent retention (Nwokocha 2016). Rewards provide employees with a sense of being valued by the organisation. Thus, there is a dearth of research in the consulting industry both nationally and internationally. Nissen (2019) asserts that as much as consulting industry is attractive to young professionals and contributes largely to the economic growth of the country, there is a scarcity of scientific research dedicated to the industry. Therefore, a research gap has been identified. It is against this background that the current study seeks to provide empirical findings that will make a valuable contribution to the implementation of retention strategies and improve performance amongst employees in the consulting industry. Thus, the aim of this study was to explore strategies to retain talent whilst ensuring performance in a consulting firm based in the south of Johannesburg.

\section{Literature review}

Various studies have indicated that talent retention is a global concern for organisations. Having the right talent in place is 
essential for organisations to remain competitive in a turbulent business environment (Oladapo 2014). Therefore, it is vital to have effective retention strategies to retain talent (Aamir et al. 2016). Additionally, talent retention strategies should be a critical aspect of an organisation's mission, vision, values and policies (Cloutier et al. 2015). Absence of talent retention strategies in organisations can be costly as employee turnover becomes disruptive to organisational bottom line. Understanding factors that cause talent to leave organisations is also critical in crafting retention strategies for an organisation. Singh (2018) attested that understanding the mindset of employees might assist organisations in understanding potential reasons for employee turnover. Retaining talent has become a challenging task because of competitive business environment (Idris 2014; Manz et al. 2014). Various factors contribute to employee turnover, which are discussed in the next section.

\section{Conceptualisation of talent retention}

Employee retention is the ability of an organisation to hold onto its employees (Fox 2012). The importance of retention prevents the loss of key employees and reduces the costs related to the high employee turnover (Samuel \& Chipunza 2009). Letchmiah and Thomas (2017:2) also stated that the longer employees are engaged in their work, their worth is likely to be evident'. Badiyala (2015) affirmed that retaining talent is another major issue with consulting firms, as it is an industry with high intra-industry mobility of talent. However, Rama Devi (2009) suggested that to improve the retention of talented employees, organisations must improve their rewards and benefits. Staff retention is therefore one of the main factors that they need to focus on. This contributes to the long-term survival of the organisation as well as sustainable profitability (Sathekge 2014).

Bussin and Toerien (2015) highlighted that if organisations do not pay attention to the rewards they offer to their employees, employee turnover is inevitable. Therefore, employee turnover is very costly to the organisation. Letchmiah and Thomas (2017) emphasised that once an organisation is able to attract and retain the most talented employees, it will lead to the success of the organisation. An organisation may benefit economically if it is able to retain its most talented employees, and this will be done through cost containment and efficient application of talent (Smit, Stanz \& Bussin 2015).

Letchmiah and Thomas (2017) are of the opinion that it is important that HR management practitioners are aware of the factors that play a crucial role in retaining employees. Different factors affect consultants on their different levels of work and it was perceived that rewards would retain talent. However, the factor that added to retention was the development opportunities that were provided to employees (Letchmiah \& Thomas 2017). Uitzinger, Chrysler-Fox and Thomas (2018) further insisted that if there is a disregard for employee wellness in the organisation, this will result in challenges in retaining top and middle-level management employees. Organisations' current top priority is talent retention because it is becoming increasingly challenging to find valuable employees (Panoch 2001). An organisation's success depends on its ability to retain its key employees (Das \& Baruah 2013). High levels of employee turnover are often related to low levels of customer satisfaction and loyalty, which decrease the profit that organisations could be gaining. High organisational turnover is expensive; aside from the replacements that must be recruited and trained, the indirect costs accumulated from the lost productivity and social capital are detrimental to the organisation (Samuel \& Chipunza 2009).

Additional losses are the knowledge, skills and connections that employees take with them when leaving the organisation (Samuel \& Chipunza 2009). This is why organisations need to place emphasis on retaining their consultants. Organisations can increase employee retention and commitment by providing their consultants with perks like flexible work schedules, training and development opportunities, health and insurance benefits and rewarding those who accomplish tasks efficiently (Deery 2008). An employee's decision to remain with the organisation is greatly related to his or her salary (Mehta, Kurbetti \& Dhankhar 2014).

Organisations that want to retain their high-performing employees should reward them with a market-related package (Mehta et al. 2014). This is important because of the high replacement costs associated with recruiting new employees (Dube, Freeman \& Reich 2010). Thus, management in the consulting industry needs to understand factors that retain their talent.

\section{Conceptualisation of rewards}

Different rewards appeal to different demographics around the world. Reward preferences are a contributing factor in attracting high-performing employees; for example, some employees may be drawn to having flexibility in the organisation, whilst some may be drawn to financial benefits. For organisations to succeed, employees are required to grow and develop themselves by taking initiative in what the organisation offers (Schaerer et al. 2017). It is important that a balance is established between the contributions an employee makes to the organisation and the rewards the organisation provides in return for the employee's contributions (Zeb et al. 2014). Furthermore, rewards systems put in place to reward employees are crucial to an organisation's ability to deliver exceptional services. Gohari et al. (2013) stated that effective rewards have a direct influence on employee performance. Bratton and Gold (2003) defined rewards as all monetary, non-monetary and psychological remuneration provided to employees in organisations for their jobs and contributions. According to Griffin, Phillips and Gully (2016):

$[R]$ ewards consist of all organisational components - people, processes, rules and decision-making activities involved in the allocation of compensation and benefits to employees in exchange for their contributions to the organisation. (p. 233) 
Herzberg's (1968) two-factor theory model views rewards as intrinsic and extrinsic. Intrinsic rewards are a derivation of what the job entails. Opportunities for promotion, recognition and autonomy are examples of intrinsic rewards in organisations. Extrinsic rewards provide employees with autonomy, which maximises their performance in their given set of tasks. Aspects such as salary, 13th cheque and incentives such as medical aid and paid public holidays are examples of extrinsic rewards (Nnaji-Ihedinmah \& Egbunike 2015). The consulting industry uses extrinsic rewards as a retention strategy for key employees (Turnea 2018). Emphasis is placed on the fact that employees derive more satisfaction in organisations when their jobs are autonomous, when targets are met and when both personal and professional development is received in the process (Dartey-Baah \& Amoako 2011). Employees value both intrinsic and extrinsic rewards as a means to remain in their designated job in the organisation. Research has placed more emphasis on the impact of monetary remuneration on optimising performance to anticipated and satisfactory standards (Nisar et al. 2017). Organisations that analyse their employees' unique needs, attitudes and aspirations are in a better position to provide rewards that would motivate employees to stay with the organisation and to perform (Michael et al. 2016). Incentives, commission and other benefits play an integral role in ensuring higher performance and talent retention in organisations.

\section{Work-life balance as a retention factor}

For organisations to be more competitive with their competitors, it is essential to maintain work and life balance of their employees. Work-life balance is described as people spending enough time on family, friends and hobbies (Kar \& Misra 2013). Kim (2014) attested that work-life balance is a balancing act and is more valued in organisations because it can have either positive or negative effects on the organisation. Therefore, satisfying work and personal responsibilities is required (Belwal \& Belwal 2014). Lunau et al. (2014) affirmed that inability to achieve work-life balance can trigger poor health. Mazerolle and Goodman (2013) attested that to achieve work-life balance amongst employees in organisations, it is essential to provide flexible work schedules, such as flexible work locations and hours. Lack of work-life balance can start to overshadow the job responsibilities (Deery \& Jago 2015; Pattusamy \& Jacob 2015). Additionally, struggling to provide work-life balance for employees can have a negative impact on employee retention. Rodríguez-Sánchez et al. (2020) stated that work-life balance can provide employees with flexibility practices that reduce stress, fatigue and conflict. For the firm, it implies higher levels of commitment, which improves productivity rates and reduces recruitment costs resulting from lower staff turnover. Hence, the implementation of worklife balance policies represents a potential retention strategy for valuable and talented HR (Rodríguez-Sánchez et al. 2020).

\section{Conceptualisation of employee performance}

Employee performance is measured in consulting organisations, thus allowing corrective measures to be taken in developing and integrating employees into the organisation. Organisations must survive in a complex and ever-changing marketplace, which requires them to continuously assess and improve performance. Kleindienst and Biedermann (2016) argued that performance management has changed tremendously over the years and that organisations have to consistently review and rework their systems to ensure that they successfully accomplish organisational goals. It is not easy for organisations to implement new performance systems, but it is important that these new implementations are carried out smoothly, especially in ensuring that employees are not placed under strenuous conditions. Presently, in order for organisations to perform well and remain competitive in the marketplace, they need to ensure that many opportunities such as promotion, long services awards and so on are used and that the organisation is able to adapt well to continuous change (Rajnoha, Lesníková \& Korauš 2016). It is the duty and responsibility of a manager to assess the type of performance management system that will be used in the organisation to encourage performance. The participation of employees is highly recommended during the process where managers make decisions. Kleindienst and Biedermann (2017) stated that, for performance management systems to be a success, top-level management should have a clear understanding of these systems and what will also be the initial benefits of using them. This then ensures that the consultants are positively influenced and are able to perform their work well. The relationships between performance, rewards, training and development of employees are factors to be considered when implementing measurement systems and ways in which they will be effective (Mabaso \& Dlamini 2018). All these factors are determinants of the performance measurement system. If performance measurement systems are not correctly implemented, and if they fail, organisational goals will not be achieved (Radebe 2013). This will result in low performance from employees and high turnover. There is an efficiency theory which states that effective rewards and good wages keep employees interested enough to continue working and improve their performance (Arokiasamy, Tat \& Bin Abdullah 2013). Performance decreases when employees perceive that an organisation is not recognising and appreciating their hard work, or when they are being rewarded poorly. Adams' equity theory speculates that there is a comparison between what employees do with regard to their input in the organisation and the amount of pay they receive (Pohler \& Schmidt 2016). Pay-for-performance is used to measure an employee's performance in relation to measuring the rewards that he or she will receive. Pay-forperformance is a driver of performance and is determined heavily by an employee's ability or inability to perform optimally (Berenson et al. 2016). Brandl and Güttel (2007) mentioned that reward systems are important when it comes to an organisation retaining its employees. Organisations in the consulting industry pursue consultants with the most talent and have to use their rewards systems in attracting and retaining them. Pay-for-performance is regarded as an extrinsic motivation for employees and is awarded to employees through means such as pay increase, bonuses or 
other incentives (Brandl \& Güttel 2007). Theuvsen (2004) stated that pay-for-performance is a link between employee performances and the monetary rewards that they receive. Profit-oriented organisations have two types of pay-forperformance plans: bonus and a value-based pay system (Theuvsen 2004). Pay-for-performance has highlighted the significance in determining how effective rewards are to a consultant's performance and retention (Snelgar 2013). If employees find a gap between these two components, for example, working hard in return for low pay or poor rewards, they are likely to reduce their performance. Employees increase their performance if they find a balance between their input in achieving the goals of the organisation and the remuneration or rewards they are given as rewards for their hard work (Safiullah 2014). In recent years, there has been a trend of linking pay to employee performance within organisations. Employers have implemented a system that is known as pay-for-performance (Pohler \& Schmidt 2016). Organisations that pay employees for their performance attract many highly skilled employees and encourage them to put great effort in their jobs to be awarded a high pay (Pratheepkanth 2011). Pay-for-performance can be seen as a source of attaining competitive advantage in the consulting industry. Employee performance is driven by a motivation that comes from being rewarded for work done well. Both monetary and non-monetary rewards are used to motivate consultants to perform better. When it comes to nonmonetary rewards, recognising employees can alter their behaviour to work hard and accomplish organisational goals; monetary rewards also encourage employees to give their best in their jobs, aiming for a salary increase or bonuses (Shahzadi et al. 2014). Rewards not only help to increase employee performance but also to ensure talent retention. An organisation that has an effective reward system has the ability to attract highly skilled employees and retain existing talented employees in their current jobs (De Gieter \& Hofmans 2015).

\section{Training and development}

Bushe (2012) defines training and development as a process of change in thought, behaviour and action, as a result of changes in knowledge, skills and competences. Training and development can enhance employee satisfaction and become a factor that indicates whether an employee stays or leaves the organisation (Akhter et al. 2016). Engaging employees in training and development widens one's compatibility with opportunities for advancement, which can allow individual to tackle new levels of responsibilities. Investing in employees gives them more incentives to stay with an organisation (Tan et al. 2014). Gharib, Kahwaji and Elrasheed (2017) found that training and development has significant effect on talent retention. This assertion mirrored the results of Dresner et al. (2014), which reveal that employees will stay longer if training and development opportunities are available. Therefore, training and development has an impact on talent retention. Management in consulting industry should pay attention to provide training and development opportunities in order to retain talent.

\section{Recognition}

According to World at Work (2021:1), recognition refers to acknowledgement or giving special attention to employee actions, efforts, behaviour or performance. It meets an intrinsic psychological need for appreciation of one's efforts and can support business strategy by reinforcing certain behaviours like extraordinary accomplishments that contribute to organisational success. Rose (2014:183) further defined recognition as a process of acknowledging or giving special attention to a high level of accomplishment or performance, such as customer care or support colleagues who are not dependent on achievement, against given targets or objectives. Vasquez (2014) attested that recognising employees' achievement increases employee morale and job satisfaction which will result in talent retention. Employees who are recognised are likely to pass the positive attitudes towards their interactions with clients (Bakar, Mohamad \& Sharmeela-Banu 2015). According to Khalid, Pahi and Ahmed (2016), employees who receive constant feedback and recognition from business leaders tend to stay with the organisations. Ali and Ahmad (2017) documented that intrinsic motivators such as pay increases and opportunities for promotion and an extrinsic motivator such as recognition can lead to higher retention rates. Furthermore, Owusu (2020) affirmed that employee recognition programmes have a positive effect on talent retention. Singh (2018) attested that employee recognition programmes increase talent retention; therefore, management must acknowledge that each employee is a critical asset and their efforts should be recognised.

\section{Career development}

Career development forms part of learning and development but depends on each organisation. McShane and Von Glinow (2015) stated that employees want opportunities to advance within the organisation and if there are no opportunities, they will leave such employers. Singh (2018) affirmed that employees that stay with an organisation seek job growth or opportunity for advancement. It is therefore significant that organisations provide conducive career development opportunities for employees (Dhanraj \& Parumasur 2014). Weng and McElroy (2012) stated that career development results in not only retention but also employee commitment. Also Darkwa et al. (2015) attested that lack of career opportunities will affect retention. This assertion is supported by Singh (2018) who affirmed that employees that perceive a lack of growth in the organisation may diminish their intent to stay, leading to voluntary turnover. Therefore, managers in the consulting industry should pay closer attention to career development as it impacts talent retention.

\section{Research design Method}

For the purpose of this study, a qualitative research was followed in order to explore retention strategies amongst consultants. A qualitative research method can be defined as 
a process of seeking an understanding of a social phenomenon in its most natural setting (Klenke, Martin \& Wallace 2015). Additionally, the current study employed an interpretivist approach that aims to look at the participants' lived experiences in detail and determines how they make sense of that personal experience (Wagner, Kawulich \& Garner 2012).

\section{Research strategy}

This study used a case study research design. A case study was used because it helped the researcher understand the phenomenon whilst at the same time considering all the conditions related to the phenomenon. Therefore, an interpretivist paradigm was employed whilst using the phenomenology approach, used with the aim of understanding the lived experiences of consultants. It also helped the researcher to investigate the contemporary phenomenon within its real-life context. A qualitative exploratory case study was used in this study. This approach was used because the aim of the study was to explore strategies to retain talent whilst enhancing employee performance in consulting industry. Additionally, the researcher aimed to identify rewards that improve performance whilst retaining talent. An exploratory case study helped the researcher gain new insight and expanded their understanding of the phenomenon (Yin 2009).

\section{Data collection}

Semi-structured interviews were used to gather data. These interviews allowed a two-way communication between the researcher and the participants and allowed the participants to express their views in their own words (Mueller \& Segal 2014). Semi-structured interviews made it possible for the participants to express their subjective, lived experiences and for the researcher to understand the meaning they attach to those experiences (Creswell 2007).

\section{Data processing}

Thematic analysis was employed to identify patterns of meaning across the data set. Nowell et al. (2017) defined thematic analysis as a method for identifying, analysing, organising, describing and reporting themes found within a data set. Data coding was conducted on the themes that were identified. Different categories and subcategories were identified and analysed to determine themes and findings. Data collected were analysed and interpreted for meaningful conclusions.

\section{Trustworthiness of the study}

Lincoln and Guba (1985) suggested that trustworthiness and rigour should be ensured in qualitative research. The following measures were employed to ensure trustworthiness: dependability, credibility, transferability and conformity. To ensure credibility, the researcher orientated by spending sufficient time in the research setting and field. Credibility was enhanced by theoretical reasoning in interpreting the findings explained. This allowed the researcher to detect and take into account own and participants' distortions that might have crept into data. During interviews and data transcription, the focus was on the phenomenon under investigation. Additionally, this was done by ensuring that participants knew they were free to refuse to take part in the study or to withdraw from the study at any stage. This ensured that the researcher only used participants who were sincerely willing to share data. The researcher established a rapport with the participants and encouraged them to be as frank as possible. Dependability in qualitative research considers the 'quality' of the understanding that the researcher obtains (Trochim 2006). In the present study, the research had raw data in the forms of recordings and transcriptions. The data reduction products included the categorising of raw data into different themes through interpretive analysis. The process notes included a thorough documentation of the process of data collection. Conformity of the present study is supported by thoroughness in data collection. The researcher had regular meetings with the study leader to ensure adherence to rules and procedures. Transferability refers to the degree to which the results of qualitative research can be transferred to other contexts with other respondents - it is the interpretive equivalent of generalisability (Bitsch 2005; Tobin \& Begley 2004). Although the sample size was relatively small, the researcher was not aiming to generalise or transfer the research findings to the experiences of all consultants. Rather, the researcher aimed to allow for in-depth information and understanding to be obtained, which could then be used as a resource for other researchers. This was achieved by providing detailed description of the enquiry and participants were selected purposively.

\section{Research setting}

The consulting firm in the current study operates in the south of Johannesburg, Gauteng province, South Africa. They are HR consulting company with wide range of HR solutions to assist organisations. They also specialise in HR compliance principles designed to assist companies with efficiency. Their services include training and development, remuneration, employment relations, health and safety, recruitment, transformation and talent management solutions. Consultants employed by the company assist organisations to provide best practices in all HR management functional areas. They also offer their services across virtually all aspects of business globally. Additionally, the industry is highly fragmented with a variety of consulting firms and service offerings.

\section{Sampling}

A non-probability sampling procedure was employed using purposive sampling technique. The participants were deliberately chosen to reflect the importance of rewards in their job performance and retention. The consultants chosen had the expertise in the consulting industry. The researcher opted to use purposive sampling because it reaches the targeted sample quickly and is a less time-consuming process as only the most appropriate participants for the study 
TABLE 1: Description of the participants' profiles.

\begin{tabular}{lllcc}
\hline Participant & Gender & Position & $\begin{array}{r}\text { Tenure } \\
\text { (years) }\end{array}$ & $\begin{array}{c}\text { Interview } \\
\text { duration (min) }\end{array}$ \\
\hline P1 & Male & Health and safety consultant & 5 & 31 \\
P2 & Female & Health and safety consultant & 5 & 28 \\
P3 & Female & Industrial relations consultant & 2 & 26 \\
P4 & Male & Industrial relations consultant & 6 & 35 \\
P5 & Male & Industrial relations consultant & 9 & 30 \\
P6 & Female & Regional manager & 7 & 34 \\
P7 & Female & Human resource consultant & 4 & 28 \\
P8 & Female & Industrial relations consultant & 5 & 27 \\
P9 & Male & Industrial relations consultant & 7 & 32 \\
P10 & Female & Industrial relations consultant & 2 & 28 \\
\hline
\end{tabular}

are selected. Twelve consultants - six men and six women from a consultancy company in Gauteng, South Africa, participated in this study. The sample included both men and women, aged between 25 and 60 years, with a minimum of 5 years' experience. These consultants were chosen because of the rich experience they had in the field of consulting (see Table 1).

\section{Data collection}

Data were collected by means of semi-structured interviews. The interview schedule consisted of 15 open-ended questions. The reason for the open-ended questions was to give an opportunity to participants to elaborate further in their responses regarding retention strategies that enhance employee performance.

\section{Data recording}

Data were recorded through field notes and transcribed. Field notes were transcribed verbatim. . The researcher made efforts to ensure all relevant and important data were captured as these enable the accuracy of data analysis.

\section{Ethical considerations}

Ethical issues are prevalent in all research studies. The process of conducting research creates conflicting views from different parties. Polit and Beck (2008) attest that ethics refers to professional, legal and sociological principles that a research needs to observe when conducting a research. It is very important to protect participants when conducting a research study. Human rights need to be the central approach when studying a phenomenon. The research focused on consultants in the consulting industry. Individual semistructured interviews were conducted with the team of consultants. Access to the participants was gained via an email invitation to participate in the study. The consultants were purposively selected to ensure that they give the researcher specific information. The purpose of the research and ethical considerations of anonymity and confidentiality were explained to all the participants. A consent form was signed by the consultants indicating their role in the research and they were assured that they are participating voluntarily and can decline participation at any time. Ethical clearance was obtained from the University of Johannesburg
TABLE 2: Main themes.

\begin{tabular}{ll}
\hline Theme & Sub-themes \\
\hline Rewards considered effective retention strategy & $\begin{array}{l}\text { Financial rewards } \\
\text { Non-financial rewards }\end{array}$ \\
Work-life balance to enhance retention & Flexitime, flexible hours \\
Performance management system & Pay-for-performance \\
Improved training and development & Skills acquisition \\
Employee recognition & Appreciation \\
& Acknowledgement \\
Career progression opportunities & Career growth \\
\hline
\end{tabular}

(reference number: IPPM 2019-187 H). In addition, permission to conduct the research was obtained from the consultancy company. Consent letters were given to target participants and the research was voluntary. Participants could withdraw from the study any time with no negative consequences. All responses were treated with confidentiality.

\section{Findings}

After conducting thematic analysis, the following themes emerged from the interviews conducted: (1) rewards considered effective retention strategy, (2) work-life balance to enhance retention, (3) performance management system, (4) improved training and development, (5) employee recognition and (6) career progression opportunities. These themes are summarised in Table 2 and explained in the discussion that follows.

As shown in Table 2, six themes were identified and subthemes are also indicated under each theme. It is evident that rewards considered effective retention strategy, work-life balance to enhance retention, performance management system, improved training and development, and employee recognition were themes that occurred frequently.

\section{Theme 1: Rewards considered effective retention strategy}

This theme relates to rewards provided by the employer to employees for enhancing employee performance, which are effective as a talent retention strategy. Both financial and non-financial rewards were frequent in the current theme. Additionally, the theme deals with rewards that are given to people in recognition of their services, efforts or achievements which enhance employee performance and retention in the organisation. A sound rewards system needs to be in place in order to remunerate consultants for the effort they put in their jobs. The sentiment amongst participants was that there is a well-structured reward in the consulting industry which enhances productivity and retention amongst employees.

The following quotes demonstrate this outlook pertaining to a reward system in the organisation:

'[T] here is a good pay structure, this encourage[ $s]$ me to go [the] extra mile in my work, the pay package helps this organisation to keep us in our jobs and not look somewhere for greener pastures.' (Participant 5, male, 43 years) 
Participant 9 (male, 34 years) said that 'they have a great commission structure, this commission motivates me to perform, if given lower commission I would likely to leave this organisation'. Participant 8 (female, 32 years) found rewards to be very good in the consulting firm, stating that 'the company has competitive rewards package, if the pay was better somewhere, I would have taken an alternative offer ... let's be honest, that's what keeps me here'.

Rewards provide motivation to employees to put more efforts in their jobs. In this segment, the findings from the participants confirm that financial rewards motivate them:

'Money is a motivator because it opens up doors which means you can do more, if I am not well-rewarded here, I should have left the company [at the] onset.' (Participant 10, female, 41 years)

Financial rewards have been identified as increasing employee performance in the consulting industry:

'[F]inancial rewards increase my performance and the organisation will prosper because of my increased performance; leaving this company is not in my plans because other companies aren't paying like my current company.' (Participant 5, male, 43 years)

'[F]inancial rewards offered by the organisation are exceptional motivator to increase performance and it demonstrates that the organisation recognise $[s]$ our hard work, and this increase $[s]$ my commitment to stay longer with the company.' (Participant 7, female, 38 years)

Participants felt that financial rewards would increase the quantity and quality of their work. These sentiments were confirmed by two consultants:

'[H]aving financial incentives shows that my hard work is appreciated and the company is willing to go [the] extra mile and give me the opportunity to challenge myself in my work; hence I am not leaving this company.' (Participant 8, female, 32 years)

\section{Additionally:}

' $[I] \mathrm{t}$ 's also about being fair compared to others, fair rewards structure offered by the organisation motivates me to do exceptional[ly] well in my work since the organisation believes in equal work for equal value that is why we are glued to this company.' (Participant 1, male, 42 years)

\section{Theme 2: Work-life balance}

This theme relates to work and life balance of consultants in the consulting firm. Additionally, work-life balance plays a critical role in talent retention. The majority (9 out of 12) of participants indicated that 'flexible working hours' is amongst the factors that contribute to retention of talents in their organisation. Flexible working hours enable the participants to create borders between work and personal life. Fostering a positive working environment is the important aspect in retaining employees. Understanding what contributes to the working conditions is a significant factor that retains them in their present jobs. Participant 6 (female, 34 years) stated, 'I am passionate about my job, I enjoy the work and company culture, most importantly flexi-hours and the interaction with different industries.' This sentiment was also echoed by Participant 5 (male, 43 years) who stated that 'competitive salary structure, flexihours, recognition and effective performance appraisal structure are among things that will keep me longer with my present organisation'. Offering flexible working hours in a consulting firm was found to be a good way to retain participants in their jobs. Participant 7 (female, 38 years) said that 'the flexi-hours, commission structure, reimbursement for travel are among factors that will retain me in this organisation'.

\section{Theme 3: Employee performance evaluation system}

Employee performance is a theme that focuses on how well employees execute their tasks or job responsibilities with the aim of achieving set organisational objectives. An established performance system in the organisation enables employees to perform outstandingly and be committed to the organisation. Employee performance is measured in consulting organisations, thus allowing corrective measures to be taken in developing and integrating employees into the organisation.

Employees should be given a fair chance to participate in this process and the results derived from this process should be used accordingly by managers to reward and develop employees. The current theme aims to determine if there was a performance management system in place, and to gauge participants if effective performance management system enhances talent retention. According to the information gathered from participants, there is currently a performance management system in place and their performance is evaluated. This is confirmed by all participants. Participant 9 (male, 34 years) said that 'there is a performance management system in place in the organisation, I am evaluated continuously and some companies do not evaluate performance'.

'[T]he performance management system is available where we sign performance contracts at the beginning of the year, we are appraised regularly by the organisation, it helps us to improve our performance and assisted when we do not meet performance standards.' (Participant 10, female, 41 years)

Additionally, the performance management system's goals are communicated to employees. This sentiment is confirmed by Participant 8 (male, 32 years) who said that 'our line managers clarify goals which assist us to be measured' and Participant 7 (female, 38 years) who stated that 'performance goals are well communicated to us and adequate support is also available to achieve those goals'. Participants also indicated that having specific performance goals enhances performance as they are inspired to work exceptionally well and exceed their expectations. Participant 1 (male, 42 years) said that 'having specific performance goals assist me to plan and prioritise my work, I can be able to seek help if I am not meeting my performance goals'. 
The organisation is recognising employee performance by means of rewards and incentives:

'I receive performance bonus at the end of the year provided that I have reached my performance targets, which motivates me to stay longer at this organisation in comparison to our competitors.' (Participant 5, male, 43 years)

The organisation offers performance incentives for good performance. Participant 1 (male, 42 years) stated that 'rewards motivate us to improve performance, if I do not get performance bonus, incentives, then I will [not] be able to work hard'. Additionally, Participant 2 (female, 37 years) said, 'I would exert more energy if I know that my performance target since I know that I will be rewarded for exceptional performance'. Participant 3 (female, 31 years) states that 'I get motivated to perform well since there are individual incentives, bonuses to enhance my performance'.

\section{Participant 4 believes that:}

' $[P]$ erformance-related pay has its own limitations and depends on the individual, it is time-specific as people may want extra money gain only for a certain amount of time, the better I perform the more I get paid - so I will continuously improve myself, this also offered me an opportunity to stay longer with the organisation.' (Participant 4, male, 35 years)

Participant 9 (female, 33 years) stated that 'performancerelated pay is a motivating factor, pay for performance enhance[s] my efforts in the tasks given to me, [I] don't see myself leaving this organisation'.

However, performance-related pay can encourage employees to work harder. Participant 5 (male, 43 years) alluded that 'I will only focus on the targets and priorities where the pay is linked to, some of my work areas will suffer if it is not linked to pay'. Similarly:

'If performance-related pay is linked to tasks, then priorities should be aligned more with overall targets in the organisation, additionally, these pay for performance packages fuel my commitment with this organisation.' (Participant 3, female, 31 years)

\section{Theme 4: Training and development that enhance retention}

Out of 12 participants, eight listed training in their answer. Change is imminent and will require the participants to better themselves and to be more equipped in this environment. Two questions were posed to the consultants under the retention topic, highlighting the importance of training and its contribution to the retention of the participants. Participant 12 (female, 29 years) said, 'I have acquired expertise in operating a computer, I didn't know how to use a computer the way I know how to use one now, so I work faster'. In a changing environment, it is critical that employees are kept abreast of latest trends in the market. Participant 11 stated:

' $[I] n$ my present job where there are changes in the legislations, policies and procedures, it is very important for me to update my knowledge, with my present manager, she prioritised that I attend all training so that I can be updated with these changes.' (Participant 11, male, 35 years)

The organisation also provided intensive training to retain employees:

'[T]he amount of training that I receive in this organisation is good and it motivates me to stay longer because of the skills that I am getting through these training initiatives.' (Participant 3, female, 31 years)

Participant 4 (male, 35 years) said, 'No, other factors motivate me, like growth in the company, self-improvement and opportunities for growth, this allow[s] me not to think about applying for jobs anywhere'. Participant 7 (female, 29 years) believes that 'self-worth, autonomy, sense of achievement and growth opportunities are the greatest motivators in the organisations; these aspects inspire me to stay longer in this organisation'. Participant 6 alluded that:

'[N]ot everyone is motivated by money; self-actualisation, passion, knowledge, job satisfaction and recognition are major motivators for me; whoever doesn't offer me these important aspects don't deserve me in their company. I'm staying in this organisation only for it.' (Participant 6, female, 34 years)

\section{Additionally:}

'I am motivated to do very well in my job because of the training and development opportunities that I receive from the company; I have been able to progress in my career and I won't leave this organisation because I'm grateful for their personal growth aspect I am given.' (Participant 3, female, 31 years)

Participant 5 (male, 43 years) said that 'new consultants are trained extensively to gain skills so that they can gain exposure to different industries and industry norms'. Training was listed as a factor that enables them to do their work easily and therefore keep them in their current jobs:

' $[W]$ ith the level of training that we receive in the company, it enable[s] me to excel in my present job, [and] I do not think that any company can invest so much money in the talent development of their employees.' (Participant 6, female, 34 years)

The participants e viewed the training provided by the organisation as beneficial to their growth and their work:

' $[T]$ raining that has been provided by the organisation has allowed me to grow in my present job; when I join $[e d]$ this company, I was working in the administration side, my line manager identified the potential in me and sent me to training, [and] I have moved to administration and working as a consultant now.' (Participant 8 , female, 32 years)

This indicates that the training that the organisation offers to the employees should not only be seen as training that can help an employee in the short term but as an investment that will boost the employee to work better in their job and that will allow the employee to engage in more productive work and see the need for further development. 


\section{Theme 5: Employee recognition}

Recognition is an important element offered by the organisation which enhances talent retention. This sentiment is alluded to by Participant 8 (female, 32 years) who indicated that 'It is nice to be recognised by line manager, but not more effective because it does not pay the bills'. Additionally, Participant 4 attested that being recognised increases employee morale, as:

'[E]mployees need frequent recognition to keep up with their good work and morale, to feel like you are doing a good [job] and being noticed motivated me to perform well in my tasks.' (Participant 4, male, 35 years)

These views were also supported by Participant 9 (male, 34 years) who affirmed that 'we have stressful job, being told you are doing very well in your job helps to keep the spirit high'. However, not everyone views recognition as an important aspect in keeping them in the organisation. Participant 3 (female, 31 years) said, 'No, I work for money, not a pat on the back, a pat on the back does not fill my bank account'. From these responses, it is evident that employee recognition plays a vital role in talent retention.

\section{Theme 6: Career progression opportunities}

Through the data that were collected, the aspect of career progression was one that all the participants regarded as something that they would want to venture in, as no one would be comfortable being in one position for their whole life. The participants indicated the importance of career progression as a retention factor. Participants expressed that they see themselves in more senior positions and that being a team leader was the first step to go to:

'[B]eing stuck in one position for three to five years is not something that I can stand for; I can leave the organisation which does not provide a progression in my career.' (Participant 10, female, 41 years)

Participant 7 (female, 38 years) said that 'to grow to be a manager and possibly a regional manager. In 2 years, I'm aiming for a team leader position.' Additionally, there are growth prospects in the organisation:

'[T]here are no red taps in the organisation, I am being prepared for a leadership position in my unit, this is encouraging to work here since I am being recognised and prepared for new career path, I will not leave the organisation.' (Participant 1, male, 42 years)

\section{Discussion}

The main aim of this study was to explore strategies to retain talent whilst ensuring performance in the consultancy firm. It has been indicated that the consultancy industry has witnessed paradigm shift in the past years which has affected employee performance and retention. Badiyala (2015) attested that employee retention has been a major challenge in the consultancy industry. However, Rama Devi (2009) suggested that to improve the retention of talented employees, organisations must improve their rewards and benefits. Staff retention is therefore one of the main factors that they need to focus on. This contributes to the long-term survival of the organisation, as well as sustainable profitability (Sathekge 2014). Bussin and Toerien (2015) highlighted that if organisations do not pay attention to the rewards they offer their employees, employee turnover is inevitable. An organisation may benefit economically if it is able to retain its most talented employees, and this will be done through cost containment and the efficient application of talent (Smit et al. 2015). An employee's decision to remain with the organisation is greatly related to their salary (Mehta et al. 2014). Organisations that want to retain their highperforming employees should reward them with a marketrelated package (Mehta et al. 2014). An organisation that has an effective reward system has the ability to attract highly skilled employees and to retain existing talented employees in their current jobs (De Gieter \& Hofmans 2015). To achieve work-life balance, organisations need to strive to provide flexible working conditions for employees. Lack of work and life balance can trigger negative health effects on employees. Mazerolle and Goodman (2013) attested that to achieve work-life balance amongst employees in organisations, it is essential to provide flexible work schedules such as flexible work locations and hours. Rodríguez-Sánchez et al. (2020) stated that work-life balance can provide employees with flexibility practices which reduce stress, fatigue and conflict. For the firm, it implies higher levels of commitment, which improves productivity rates and reduces recruitment costs resulting from lower staff turnover. Hence, the implementation of work-life balance policies represents a potential retention strategy for valuable and talented HR (Rodríguez-Sánchez et al. 2020).

For an organisation to remain competitive, it is essential to measure the performance of their workforce. Markova and Ford (2012) stated that organisational performance can be traced to the willingness of employees to deploy their creativity, abilities and expertise for the attainment of organisational goals. The findings of the study show that participants are highly motivated to increase their performance if they are rewarded. Misra et al. (2012) affirmed that rewards are vital to the employment relationship and play a critical role in maintaining high levels of employee performance. Additionally, Nwokocha and Iheriohanma (2013) stated that rewards influence the performance of employees by recognising and rewarding good performance. This shows that financial rewards play a bigger role in keeping employees at a consulting firm motivated. This sentiment is echoed by Nwokocha (2016) who postulated that employee rewards have an impact on performance whilst ensuring talent retention. A very consistent theme that arose from the participants' responses was performancerelated pay. Participants who claimed that they are motivated by pay-for-performance are assumed to be extrinsically motivated. It is no surprise that majority of the participants are motivated by pay-for-performance. Performance-related pay rewards encourage higher employee performance 
amongst employees. Rewards influence the performance of employees by recognising and rewarding good performance (Nwokocha \& Iheriohanma 2013). Participants' responses proved that they are motivated by the money they are rewarded for their high performance. Snelgar (2013) attested that rewarding high performance is significant for employee performance and retention. It is evident that the majority of participants at this consulting firm are motivated to increase their performance by financial rewards; some participants are motivated by non-financial rewards. Although monetary rewards have proven for many years to be effective in increasing performance, time has shifted, and many types of non-monetary rewards have been introduced, which now appear to be more important to employees in keeping them motivated to perform optimally. This is in line with Herzberg's (1968) two-factor theory which views both intrinsic and extrinsic rewards. Nnaji-ihedinmah and Egbunike (2015) differentiated between intrinsic and extrinsic rewards. Intrinsic rewards are a derivation of what the job entails. Opportunities for promotion, recognition and autonomy are examples of intrinsic rewards in organisations. Extrinsic rewards provide employees with an autonomy, which maximises their performance in their given set of tasks. Aspects such as salary, 13th cheque and incentives such as medical aid, paid public holidays and lunches are examples of extrinsic rewards (Nnaji-Ihedinmah \& Egbunike 2015). Employees value both intrinsic and extrinsic rewards as a means to remain in their designated job in the organisation. Research has placed more emphasis on the impact of monetary remuneration on optimising performance to anticipated and satisfactory standards (Nisar et al. 2017). Organisations that analyse their employees' unique needs, attitudes and aspirations are in a better position to provide rewards that would motivate employees to stay with the organisation and to perform (Michael et al. 2016).

Training and development increases job knowledge and assists employees to achieve current and future goals of the organisation. It is essential that organisations invest on training and development because of benefits it brings to the organisations. Gharib et al. (2017) found that training and development has significant effect on talent retention. This assertion mirrored the results of Dresner et al. (2014), which revealed that employees will stay longer if training and development opportunities are available. Therefore, training and development has an impact on talent retention. Management in consulting industry should pay attention to providing training and development opportunities in order to retain talent.

Another aspect that enhances talent retention and becomes a factor that indicates whether employees stay or leave the organisation is the availability of career progression opportunities. Singh (2018) affirmed that employees who stay with an organisation seek job growth or opportunity for advancement. Dhanraj and Parumasur (2014) affirmed that organisations need to provide conducive career development opportunities for employees (Dhanraj \& Parumasur 2014). Lack of career development fuels voluntary turnover amongst employees. Darkwa et al. (2015) attested that lack of career opportunities will affect retention. This assertion is supported by Singh (2018) who affirmed that employees who perceive a lack of growth in the organisation may diminish their intent to stay, leading to voluntary turnover. Therefore, managers in the consulting industry need to pay closer attention to rewards, work-life balance, performance management, career development and career progression opportunities, as these factors impact talent retention.

\section{Limitations of the study}

The limitations that have been identified in our research include the sample and the location of study. The current study was limited to a single organisation in the Gauteng province. A second limitation was the usage of specific target population, namely, consultants employed in the consulting organisation. The sample size was 12 participants, which was too small to generalise the data of the entire population. The study findings could therefore not be generalised to the entire consulting industry.

\section{Recommendations}

It is recommended that managers take into consideration these factors, namely, rewards, work-life balance, performance management, career development and career progression opportunities, as these are strategies to retain talent in the consulting industry. The management should also consider that different employees are motivated by different kinds of rewards in organisations. Understanding and identification of what motivates employees to stay or leave the organisation is essential and could minimise the financial costs of resources, such as recruitment and selection costs. Development and implementation of retention strategies can lead to policies and practices aiming to assist organisations to maintain their human capital. Therefore, the findings of the present study could potentially benefit organisations by providing insights into information that might assist to improve talent retention. Management and business should practise and echo the values they have instilled in the business; this will not only display that the employees are looked after or appreciated but that they are also part of the good culture, which employees deem challenging to go out of. Management should understand that when it may come to the planning for the success and growth of the organisation or business, they should consider taking their human capital as one of their biggest factors. Human resources should be able to plan the training and development of the employees, with manager's contributions. Future studies can be conducted at broad spectrum as the current study was only based in Gauteng province.

\section{Conclusion}

The consulting industry needs to pay attention to factors that affect retention of talent, and these factors can be used to develop retention strategy for the organisations. Therefore, it is advisable that management in consulting firms develop 
their own retention strategy; as organisations are not the same, a one-size-fits-all approach will not be ideal in this regard. Implementation of an effective strategy is critical if organisations want to retain talent. Retention strategy will ensure sustainability in the industry as organisations rely greatly on talent for their survival. Organisational leaders should also develop a monitoring tool that will help managers to decipher what strategies are working and what strategies are not working. Therefore, a proactive approach should be developed rather than a reactive approach.

\section{Acknowledgements}

The authors would like to thank consultants who participated in the study. Additionally, they would like to thank the useful insights provided by the anonymous reviewers, which enabled them to improve the article.

\section{Competing interests}

The authors declare that they have no financial or personal relationships that may have inappropriately influenced them in writing this article.

\section{Authors' contributions}

C.M.M. is the study supervisor and compiled the article. M.T.M., M.K., L.L., S.S.M. and M.T.K. were students.

\section{Funding information}

This research received no specific grant from any funding agency in the public, commercial, or not-for-profit sectors.

\section{Data availability}

Data sharing is not applicable to this article as no new data were created or analysed in this study.

\section{Disclaimer}

The views and opinions expressed in this article are those of the authors and do not necessarily reflect the official policy or position of any affiliated agency of the authors.

\section{References}

Aamir, A., Hamid, A.B.A., Haider, M. \& Akhtar, C.S., 2016, 'Work-life balance, job satisfaction and nurses retention: Moderating role of work volition', Internationa Journal of Business Excellence 10(4), 488-501. https://doi.org/10.1504/ IJBEX.2016.079257

Akhter, N., Raza, H., Ashraf, A., Ahmad, A. \& Aslam, N., 2016, 'Impact of training and development, performance appraisal and reward system on job satisfaction', International Review of Management and Business Research 5(2), 561-578.

Ali, M. \& Ahmad, N., 2017, 'Impact of pay promotion and recognition on job satisfaction: A study on banking sector employees Karachi', Global Management Journal for Academic \& Corporate Studies 7, 131-141.

Al Mamun, C.A. \& Hasan, M.N., 2017, 'Factors affecting employee turnover and sound retention strategies in business organisation: A conceptual view', Problems and Perspectives in Management 15(1), 63-71. https://doi.org/10.21511/ ppm.15(1).2017.06

Arokiasamy, A.R.A., Tat, H.H. \& Bin Abdullah, A.G.K., 2013, 'The effects of reward system and motivation on job satisfaction: Evidence from the education industry in Malaysia', World Applied Sciences Journal 24(12), 1597-1604.

Badiyala, A., 2015, 'Attracting, retaining and developing the best consulting talent', Drishtikon 2015-16 at XLRI
Bakar, J.A., Mohamad, Z.Z. \& Sharmeela-Banu, S.A., 2015, 'Factors affecting female lecturer retention in private higher institution in Perak', International Journal of Academic Research in Business and Social Sciences 5(1), 137-146. https://doi. Academic Research in Business
org/10.6007/IJARBSS/v5-i1/1410

Belwal, S. \& Belwal, R., 2014, 'Work-life balance, family-friendly policies and quality of work life issues: Studying employers' perspectives of working women in Oman', Journal of International Women's Studies 15(1), 96-117.

Berenson, R.A., Upadhyay, D., Delbanco, S.F. \& Murray, R., 2016, Payment methods: How they work, Urban Institute, Washington, DC.

Bitsch, V., 2005, 'Qualitative research: A grounded theory example and evaluation criteria', Journal of Agribusiness 23(345-2016-15096), 75-91.

Brandl, J. \& Güttel, W.H., 2007, 'Organisational antecedents of pay-for-performance systems in nonprofit organisations', Voluntas: International Journal of Voluntary and Nonprofit Organisations 18(2), 176-199. https://doi.org/10.1007/s11266007-9036-6

Bratton, J. \& Gold, J., 2003, Human resource management: Theory and Practice, Palgrave Macmillan, Basingstoke.

Brian, E., 2009, 'Employees supervision', Journal of Human Resource Management $21(1), 3-13$

Bushe, B., 2012, 'Factors that determine academic staff retention and commitment in private tertiary institutions in Botswana: Empirical review', Global Advanced Research Journal of Management and Business Studies 1(9), 278-299.

Bussin, M. \& Toerien, W.C., 2015, 'Influence of reward preferences in attracting, retaining, and motivating knowledge workers in South African information technology companies', Acta Commercii 15(1), 1-13. https://doi.org/10.4102/ ac.v15i1.290

Callakoppen, L.R., 2016, 'The impacts of rewards on motivation on staff at a medical service organisation', Master's thesis, University of Johannesburg.

Cloutier, O., Felusiak, L., Hill, C. \& Pemberton-Jones, E.J., 2015, 'The importance of developing strategies for employee retention', Journal of Leadership, Accountability \& Ethics 12(2), 119-136.

Consultancy, 2018, Trends and challenges in the management consulting industry, Consultancy, Pretoria.

Creswell, J.W., 2007, Qualitative inquiry and research design: Choosing among five approaches, 3rd edn., Sage, Thousand Oaks, CA.

Darkwa, K.W., Newman, S., Kawkab, M. \& Chowdhury, E.M., 2015, 'A qualitative study of factors influencing retention of doctors and nurses at rural healthcare facilities in Bangladesh', BMC Health Services 15, 344. https://doi.org/10.1186/s12913015-1012-z

Dartey-Baah, K. \& Amoako, G.K., 2011, 'Application of Frederick Herzberg's two-factor theory in assessing and understanding employee motivation at work: A Ghanaian perspective', European Journal of Business and Management 3(9), 1-8.

Das, B.L. \& Baruah, M., 2013, 'Employee retention: A review of literature', Journal of Business and Management 14(2), 8-16. https://doi.org/10.9790/487X-1420816

Deery, M., 2008, 'Talent management, work-life balance and retention strategies', International Journal of Contemporary Hospitality Management 20(7), 792-806. https://doi.org/10.1108/09596110810897619

Deery, M. \& Jago, L., 2015, 'Revisiting talent management, work-life balance and retention strategies', International Journal of Contemporary Hospitality Management 27(3), 453-472. https://doi.org/10.1108/IJCHM-12-2013-0538

De Gieter, S. \& Hofmans, J., 2015, 'How reward satisfaction affects employees' turnover intentions and performance: An individual differences approach', Human Resource Management Journal 25(2), 200-216. https://doi. org/10.1111/1748-8583.12072

Dhanraj, D. \& Parumasur, S.B., 2014, 'Employee perceptions of job characteristics and challenges of job rotation', Corporate Ownership \& Control 12(1-8), 733-741. https://doi.org/10.22495/cocv12i1c8p6

Dresner, M., De Rivera, C., Fuccillo, K.K. \& Heejun, C., 2014, 'Improving higher-order thinking and knowledge retention in environmental science teaching', BioScience 64(1), 40-48. https://doi.org/10.1093/biosci/bit005

Dube, A., Freeman, E. \& Reich, M., 2010, Employee replacement costs, IRLE Working Paper No. 201-10, viewed 23 November 2020, from https://irle.berkeley.edu/ files/2010/Employee-Replacement-Costs.pdf.

Fox, R.J., 2012, 'A study of employee retention issues in the hospitality industry', Doctoral dissertation, University of Wisconsin.

Gharib, M.N., Kahwaji, A.T. \& Elrasheed, M.O., 2017, 'Factors affecting staff retention strategies used in private Syrian companies during the crisis', International Review of Management and Marketing 7(2), 202-206.

Gohari, P., Ahmadloo, A., Boroujeni, M.B. \& Hosseinpour, S.J., 2013, 'The relationship between regards and employee performance', Interdisciplinary Journal of Contemporary Research in Business 5(3), 543-554.

Griffin, R.W., Phillips, J.M. \& Gully, S.M., 2016, Organisational behaviour: Managing people and organisations, Cengage Learning, London.

Hall-Ellis, S., 2014, 'Reward systems promote high-performance work teams achieving library mission', The Bottom Line 27(2), 66-69. https://doi.org/10.1108/BL-042014-0011

Herzberg, F., 1968, 'One more time: How do you motivate employees?', Harvard Business Review 40(1), 53-62.

Idris, A., 2014, 'Flexible working as an employee retention strategy in developing countries', Journal of Management Research 14, 71-86. 
Kar, S. \& Misra, C.K., 2013, 'Nexus between work life balance practices and employee retention - The mediating effect of a supportive culture', Asia Journal of Social Science 9(11), 1911-2017, 1911-2025. https://doi.org/10.5539/ass.v9n11P63

Khalid, N., Pahi, M.H. \& Ahmed, U., 2016, 'Losing your best talent: Can leadership retain employees? The dilemma of the banking sector of Hyderabad Sindh Pakistan: A mediation investigation', International Review of Management and Marketing 6(3), 608-616.

Kim, H.K., 2014, 'Work-life balance and employees' performance: The mediating role of affective commitment', Global Business and Management Research 6(1) 37-51.

Kleindienst, B. \& Biedermann, H., 2016, 'Participatory development of a performance measurement and management system', Proceedings of 8th International Scientific Conference-Management of Technology Step to Sustainable Production, Scientific Conference-Managem
Poreč, Croatia, June 01, 2016.

Klenke, K., Martin, M. \& Wallace, J.R., 2015, Qualitative research in the study of leadership, 2nd edn., Emerald Group Publishing Limited, London.

Kwenin, D.O., Muathe, S. \& Nzulwa, R., 2013, 'The influence of employee rewards, human resource policies and job satisfaction on the retention of employees in Vodafone Ghana Limited', European Journal of Business and Management 5(12) 13-20.

Larkin, I. \& Pierce, L., 2015, 'Compensation and employee misconduct: The inseparability of productive and counterproductive behavior in firms', in D. Palmer, R. Greenwood \& K. Smith-Crowe (eds.), Organisational wrongdoing: Key perspectives and new directions, pp. 1-27, Cambridge University Press, perspectives

Letchmiah, L. \& Thomas, A., 2017, 'Retention of high-potential employees in a development finance company', SA Journal of Human Resource Management 15(0), 1-9. https://doi.org/10.4102/sajhrm.v15i0.924

Liberty, C.K., 2017, 'The contribution of reward systems to enhance employee engagement', Master's dissertation, Nelson Mandela Metropolitan University.

Lincoln, Y.S. \& Guba, E.G., 1985, Naturalistic inquiry, Sage, Newbury Park, CA.

Lunau, T., Bambra, C., Eikemo, T.A., Van der Wel, K.A. \& Dragano, N., 2014, 'A balancing act? Work-life balance, health and well-being in European welfare states', European Journal of Public Health 24(3), 422-427. https://doi.org/10.1093/ eurpub/cku010

Mabaso, C.M. \& Dlamini, B.I., 2018, 'Total rewards and its effects on organisational commitment in higher education institutions', SA Journal of Human Resource Management 16(0), 1-8. https://doi.org/10.4102/sajhrm.v16i0.913

Manz, C.C., Fugate, M., Hom, P.W. \& Millikin, J.P., 2014, 'When having to leave is a "Good Thing" A case for positive involuntary turnover', Organizational Dynamics 44(1), 57-64. https://doi.org/10.1016/j.orgdyn.2014.11.007

Markova, G. \& Ford, C., 2011, 'Is money the panacea? Rewards for knowledge workers', International Journal of Productivity and Performance Management 60(8), 813-823. https://doi.org/10.1108/17410401111182206

Mazerolle, S.M. \& Goodman, A., 2013, 'Fulfillment of work-life balance from the organizational perspective: A case study', Journal of Athletic Training 48(5), 668-677. https://doi.org/10.4085/1062-6050-48.3.24

McShane, S.L. \& Von Glinow, M.A., 2015, Organizational behavior: Emerging knowledge, global reality, 7th edn., McGraw-Hill Education, Singapore.

Mehta, M., Kurbetti, A. \& Dhankhar, R., 2014, 'Study on employee retention and commitment', International Journal of Advance Research in Computer Science and Management Studies 2(2), 154-164.

Michael, B., Prince, A.F. \& Chacko, A., 2016, 'Impact of compensation package on employee retention', International Journal of Research in Commerce and Management 7(10), 36-40.

Misra, P., Rana, N. \& Dixit, V., 2012, 'Compensation: Impact of rewards, organisational justice on job satisfaction and turnover intentions in retail store operations', Proceedings of the International Conference on Business Management \& Information Systems, Singapore, November 24, 2012, pp. 405-415.

Mueller, A.E \& Segal, D.L., 2014, 'Structured versus semi structured versus unstructured interviews', The Encyclopedia of Clinical Psychology. https://doi. org/10.1002/9781118625392.wbecp069

Nisar, Q.A., Ahmad, Z., Ali, L. \& Ahmed, I., 2017, 'Impact of rewards, recognition and job stress on job performance and job satisfaction', International Journal for Research in Business, Management and Accounting 3(4), 1-17.

Nissen, V., 2019, Advances in consulting research recent findings and practical cases, 1 st edn., Springer International Publishing, Ilmenau. https://doi.org/10.1007/9783-319-95999-3

Nnaji-Ihedinmah, N.C. \& Egbunike, F.C., 2015, 'Effect of rewards on employee performance in organisations: A study of selected commercial banks in Awka Metropolis', European Journal of Business and Management 7(4), 80-88.

Nowell, L.S., Norris, J.M., White, D.E. \& Moules, N.J., 2017, 'Thematic analysis: Striving to meet the trustworthiness criteria', International Journal of Qualitative Methods 16(1), 1609406917733847.

Nwokocha, I., 2016, 'Managing reward strategy to enhance employee performance, retention and productivity in organisations: A general overview', International Journal of Development and Management Review 11(1), 20-38.

Nwokocha, I. \& Iheriohanma, L., 2013, 'Emerging trends employee retention strategies in a globalizing', Asian Social Sciences 198-204. https://doi.org/10.5539/ass. v8n10p198

Oladapo, V., 2014, 'The impact of talent management on retention', Journal of Business Studies Quarterly 5(3), 19-36.
Owusu, M.A., 2020, 'Strategies to improve employee retention in the small retail industry', Doctoral dissertation, Walden University.

Panoch, A., 2001, 'The relationship between diversity and employee retention', Master's dissertation, Graduate School University of Wisconsin.

Pattusamy, M. \& Jacob, J., 2015, 'Testing the mediation of work-family balance in the relationship between work-family conflict and job and family satisfaction', South African Journal of Psychology 46(2), 218-231. https://doi. org/10.1177/0081246315608527

Pohler, D. \& Schmidt, J.A., 2016, 'Does pay-for-performance strain the employment relationship? The effect of manager bonus eligibility on non-management employee turnover', Personnel Psychology 69(2), 395-429. https://doi.org/10.1111/peps.12106

Polit, D.F. \& Beck, C.T., 2008, Nursing research: Generating and assessing evidence for nursing practice, 8th edn., Wolters Kluwer Health/Lippincott Williams \& Wilkins, Philadelphia, PA.

Pratheepkanth, P., 2011, 'Reward system and its impact on employee motivation in commercial bank of Sri Lanka plc, in Jaffna District', Global Journal of Management and Business Research 11(4), 85-92.

Pregnolato, M., Bussin, M. \& Schlechter, A., 2017, 'Total rewards that retain: A study of demographic preferences', South African Journal of Human Resource Management 15, a804, 1-10. https://doi.org/10.4102/sajhrm.v15.804

Radebe, P.Q., 2013, 'The impact of a performance management system on service delivery in the City of Johannesburg Metropolitan Municipality', Doctoral dissertation, North-West University.

Rajnoha, R., Lesníková, P., Korauš, A., 2016, 'From financial measures to strategic performance measurement system and corporate sustainability: Empirical evidence from Slovakia', Economics and Sociology 9(4), 134-152. https://doi. org/10.14254/2071-789X.2016/9-4/8

Rama Devi, V., 2009, 'Employee engagement is a two-way street', Human Resource Management International Digest 17(2), 3-4. https://doi. org/10.1108/09670730910940186

Rodríguez-Sánchez, J.-L., González-Torres, T., Montero-Navarro, A. \& Gallego-Losada, R., 2020, 'Investing time and resources for work-life balance: The effect on talent retention', International Journal of Environmental Research and Public Health 17(6), 2-14. https://doi.org/10.3390/ijerph17061920

Rose, M., 2014, Reward management, Kogan Page, London.

Safiullah, A.B., 2014, 'Impact of rewards on employee motivation of the telecommunication industry of Bangladesh: An empirical study', Journal of Business and Management 16(12), 22-30. https://doi.org/10.9790/487X-161222230

Samuel, M.O. \& Chipunza, C., 2009, 'Employee retention \& turnover: Using motivational variables as a panacea', African Journal of Business Management 3(8), 410-415.

Sathekge, M.J., 2014, 'An examination of factors impacting on talent retention at a financial institution', Unpublished thesis, University of Johannesburg.

Schaerer, M., Kern, M., Berger, G., Medvec, V. \& Swaab, R., 2017, 'The illusion of transparency in performance appraisals: When and why accuracy motivation explains unintentional feedback inflation', Organisational Behavior and Human Decisions Processes 144, 171-186.

Shahzadi, I., Javed, A., Pirzada, S., Nasreen, S. \& Khanam, F., 2014, 'Impact of employee motivation on employee performance', European Journal of Business and Management 6(23), 159-166.

Singh, A., 2018, 'Employee retention strategies in Trinidadian small enterprises', Doctoral dissertation, Walden University.

Smit, W., Stanz, K. \& Bussin, M., 2015, 'Retention preferences and the relationship between total rewards, perceived organisational support and perceived supervisor support', SA Journal of Human Resource Management 13(1), 1-13. https://doi.org/10.4102/sajhrm.v13i1.665

Snelgar, R.J., Renard, M. \& Venter, D., 2013, An empirical study of the reward preferences of South African employees', SA Journal of Human Resource Management 11(1), 84-97. http://dx.doi.org/10.4102/sajhrm.v11i1.351

Srinivasan, R., 2014, 'The management consulting industry: Growth of consulting services in India: Panel discussion', IIMB Management Review 26(4), 257-270. https://doi.org/10.4102/sajhrm.v13i1.665

Tan, B.I., Nadarajah, S., Sim, J.J. \& Ng, C.C., 2014, 'Soft TQM practices, customer orientation and business performance: A proposed structural model', International Journal of Modelling in Operations Management 4(1/2), 21-34. https://doi. org/10.1504/IJMOM.2014.063577

Theuvsen, L., 2004, 'Doing better while doing good: Motivational aspects of pay-forperformance effectiveness in nonprofit organisations' Voluntas: International Journal of Voluntary and Nonprofit Organisations 15(2), 117-136. https://doi. org/10.1023/B:VOLU.0000033177.16367.e3

Tobin, G.A. \& Begley, C.M., 2004, 'Methodological rigour within a qualitative framework', Journal of Advanced Nursing 48(4), 388-396. https://doi. org/10.1111/j.1365-2648.2004.03207.x

Trochim, W., 2006, The research methods knowledge base, viewed 30 November 2020, from https://conjointly.com/kb/.

Turnea, E.S., 2018, 'Attraction and retention of the employees. A study based on multinationals from Romania', Procedia-Social and Behavioral Sciences 238, 73-80. https://doi.org/10.1016/j.sbspro.2018.03.009

Uitzinger, D., Chrysler-Fox, P. \& Thomas, A., 2018, 'Perceptions of human resource professionals of challenges to and strategies for retaining managers', Acto Commercii 18(1), 1-10. https://doi.org/10.4102/ac.v18i1.504 
Vasquez, D., 2014, 'Employee retention for economic stabilization: A qualitative phenomenological study in the hospitality sector', International Journal of Management, Economics and Social Sciences 3(1), 1-17, viewed from http:// Mwww.ijmess.com

Victor, J. \& Hoole, C., 2017, 'The influence of organisational rewards on workplace trust and work engagement', SA Journal of Human Resource Management 15(0), 1-14. https://doi.org/10.4102/sajhrm.v15i0.853

Wagner, C., Kawulich, B. \& Garner, M. (eds.), 2012, Doing social research: A global context, McGraw-Hill, Maidenhead.

Weng, Q. \& McElroy, J.C., 2012, 'Organizational career growth, affective occupational commitment and turnover intentions', Journal of Vocational Behavior 80(2), 256-265. https://doi.org/10.1016/j.jvb.2012.01.014
Work Institute, 2019, Retention report, viewed 21 May 2020, from https://info. workinstitute.com/hubfs/2019\%20Retention $\% 20$ Report/Work $\% 20$ Institute $\% 20$ 2019\%20Retention\%20Report\%20final-1.pdf.

World at Work, 2021, Total rewards model a framework for strategies to attract, motivate and retain employees, viewed 15 February 2021, from http://www. worldatwork.org/waw/adimLink?id=28330.

Yin, R.K., 2009, Case study research: Design and methods, 4th edn., Sage, Thousand Oaks, CA.

Zeb, A., Rehman, S.U., Saeed, G. \& Ullah, H., 2014, 'A study of the relationship between reward and recognition and employees job satisfaction: A literature review' Abasyn Journal of Social Sciences 7(2), 295. 